\title{
Supplementary Information
}

\section{Single Potassium-Ion Conducting Polymer Electrolytes: Preparation, Ionic Conductivities, and Electrochemical Stability}

\author{
Jingfeng Zheng, Luke Schkeryantz, Gerald Gourdin, Lei Qin, and Yiying Wu \\ Department of Chemistry and Biochemistry, The Ohio State University, 100 West $18^{\text {th }}$ Avenue, \\ Columbus, Ohio 43210, United States
}




\section{Synthesis of the monomers:}

\section{1,1,1-trifluoro-N-(4-vinylphenyl)methanesulfonamide (HSTFSA)}

In general, $42 \mathrm{mmol}(1.0 \mathrm{eq}, 5.0 \mathrm{~g})$ of 4-aminostyrene and $71 \mathrm{mmol}(1.7 \mathrm{eq}, 7.2 \mathrm{~g})$ of triethylamine (TEA) were dissolved in $100 \mathrm{~mL}$ dry dichloromethane (DCM) within a $500 \mathrm{~mL}$ round bottom flask. Then, $50 \mathrm{mmol}$ (1.2 eq, $14.2 \mathrm{~g}$ ) of trifluoromethanesulfonic anhydride was dissolved in $40 \mathrm{~mL}$ dry DCM. The trifluoromethanesulfonic anhydride solution was added dropwise into the amine solution at $-78^{\circ} \mathrm{C}$. After addition, the reaction was allowed to warm up to room temperature and stirred 24 hours. The whole reaction was conducted under an inert atmosphere.

After completely reacting, $10 \mathrm{~mL}$ DI water was added into the solution to quench the reaction. 4 $\mathrm{M} \mathrm{NaOH}$ solution was added to the crude until the $\mathrm{pH}$ of the aqueous phase was above 13 . The aqueous phase was washed with DCM three time to remove any organic byproducts and trimethylamine. The aqueous layer was then collected and brought to a $\mathrm{pH}$ below 1 with $5 \mathrm{M} \mathrm{HCl}$ solution to fully protonate the sulfonamide. The resulting acidic aqueous solution was extracted with DCM three times. The organic phases were combined and dried with anhydrous sodium sulfate $\left(\mathrm{Na}_{2} \mathrm{SO}_{4}\right)$. The crude was finally purified by column chromatography (silica, hexane/ethyl acetate, $5: 1, \mathrm{Rf}=0.3)$ and rotary evaporation to get the targeted product [1,1,1-trifluoro-N-(4vinylphenyl)methanesulfonamide] (HSTFSA) $\left(8.0 \mathrm{~g}\right.$, yield 76\%). ${ }^{1} \mathrm{H}$ NMR $\left(400 \mathrm{MHz} ; \mathrm{CDCl}_{3}\right) \delta$ $7.62(\mathrm{~s}, 1 \mathrm{H}), 7.47-7.38(\mathrm{~m}, 2 \mathrm{H}), 7.31-7.24(\mathrm{~m}, 2 \mathrm{H}), 6.71(\mathrm{dd}, \mathrm{J}=17.6,10.9 \mathrm{~Hz}, 1 \mathrm{H}), 5.77$ (dd, $\mathrm{J}=17.6,0.7 \mathrm{~Hz}, 1 \mathrm{H}), 5.32(\mathrm{dd}, \mathrm{J}=10.8,0.8 \mathrm{~Hz}, 1 \mathrm{H}) .{ }^{19} \mathrm{~F} \mathrm{NMR}\left(376 \mathrm{MHz} ; \mathrm{CDCl}_{3}\right): \delta=-75.37(\mathrm{~s}$, $3 \mathrm{~F})$.

Potassium ((trifluoromethyl)sulfonyl)(4-vinylphenyl)amide (KSTFSA) 
The acid sulfonamide was converted to the potassium salts by reacting with 3 equivalents of potassium carbonate in acetonitrile for 24 hours. The excess carbonate was removed by filtration. The solvent was removed by rotary evaporation. The salt did not need any further purification. [potassium ((trifluoromethyl)sulfonyl)(4-vinylphenyl)amide] (KPSTFSA) ${ }^{1} \mathrm{H}$ NMR (400 MHz; DMSO-6d) $7.21-7.13(\mathrm{~m}, 2 \mathrm{H}), 6.99-6.81(\mathrm{~m}, 2 \mathrm{H}), 6.59$ (dd, J = 17.6, $10.9 \mathrm{~Hz}, 1 \mathrm{H}), 5.56(\mathrm{dd}, \mathrm{J}$ $=17.6,1.3 \mathrm{~Hz}, 1 \mathrm{H}), 5.01(\mathrm{dd}, \mathrm{J}=10.9,1.2 \mathrm{~Hz}, 1 \mathrm{H}) .{ }^{19} \mathrm{~F}$ NMR $(376 \mathrm{MHz}$; DMSO): $\delta=-75.65(\mathrm{~s}$, $3 \mathrm{~F})$. 


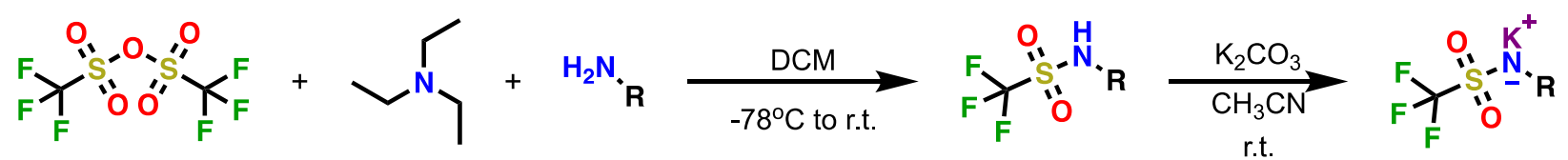

Scheme S1. General synthetic route for the monomer 


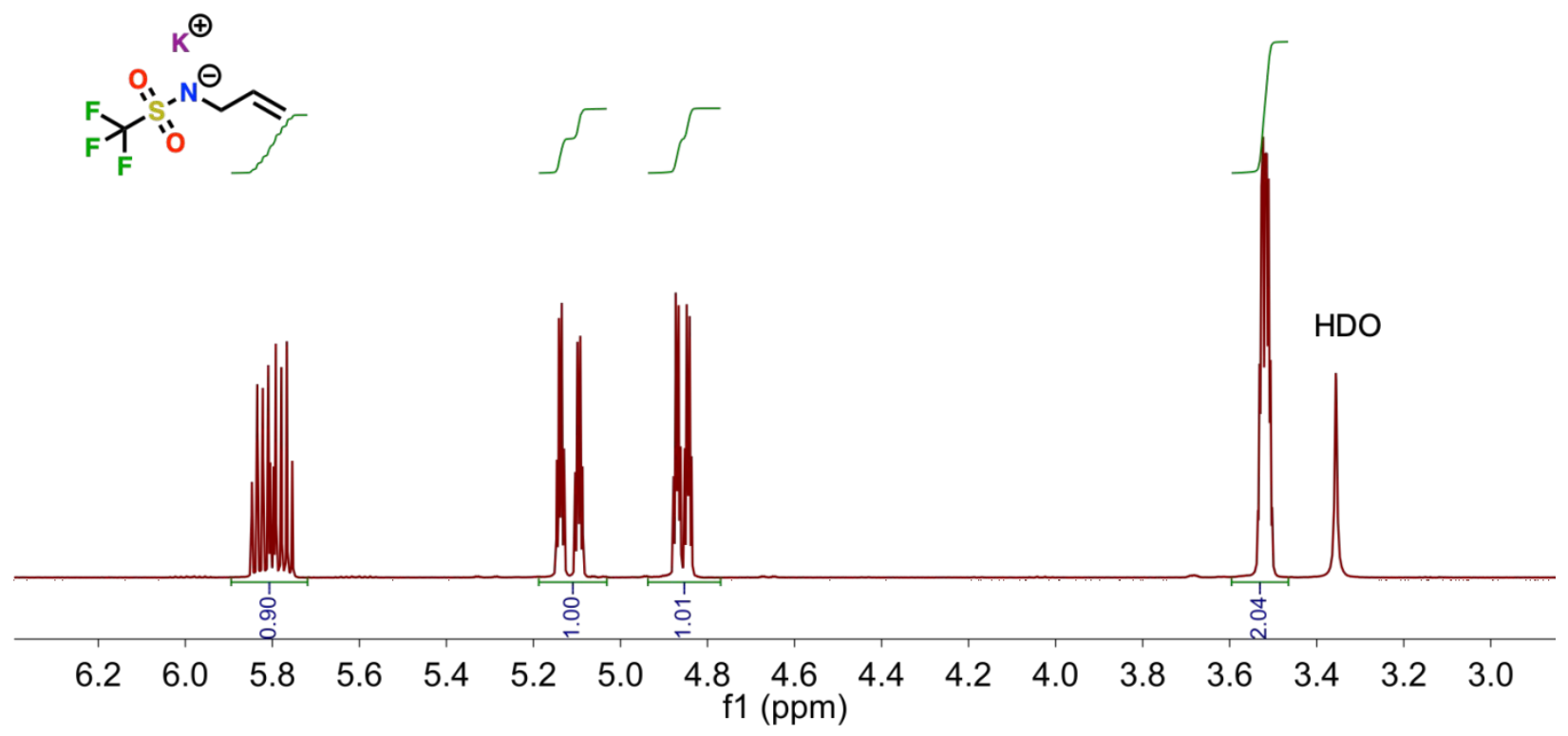

Figure S1. ${ }^{1} \mathrm{H}$ NMR spectra of propylene-type monomer in DMSO 


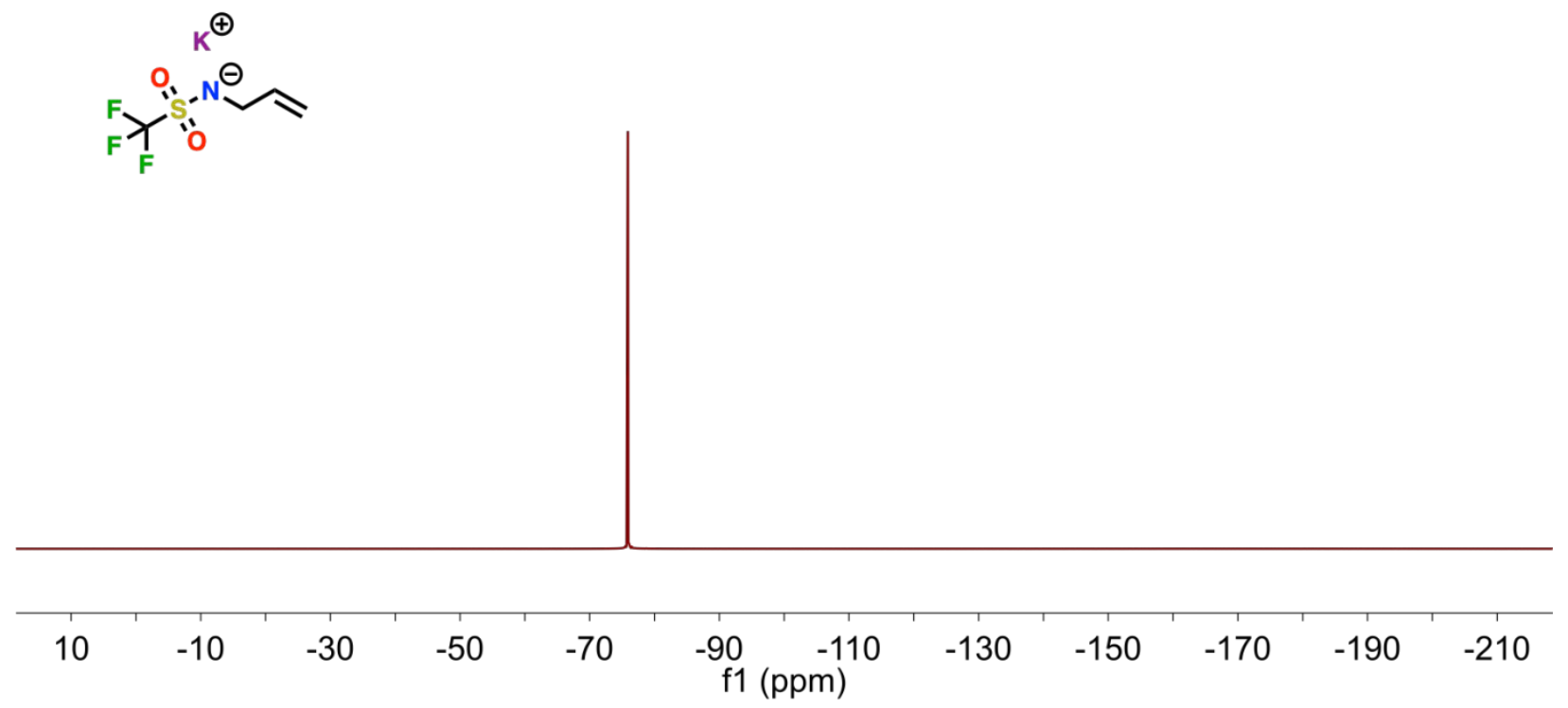

Figure S2. ${ }^{19} \mathrm{~F}$ NMR spectra of propylene-type monomer in DMSO 

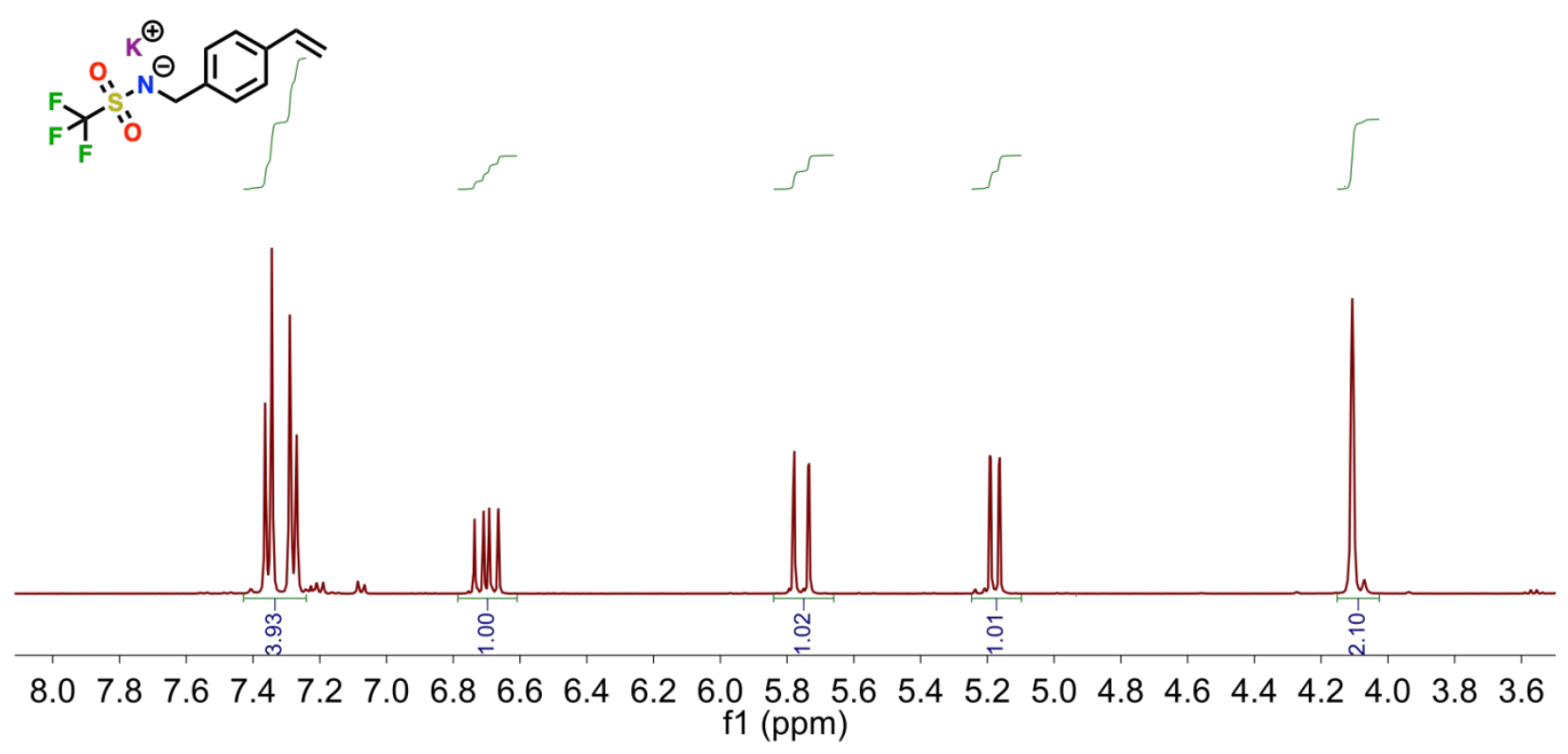

Figure S3. ${ }^{1} \mathrm{H}$ NMR spectra of 4-methyl-styrene-type monomer in DMSO 


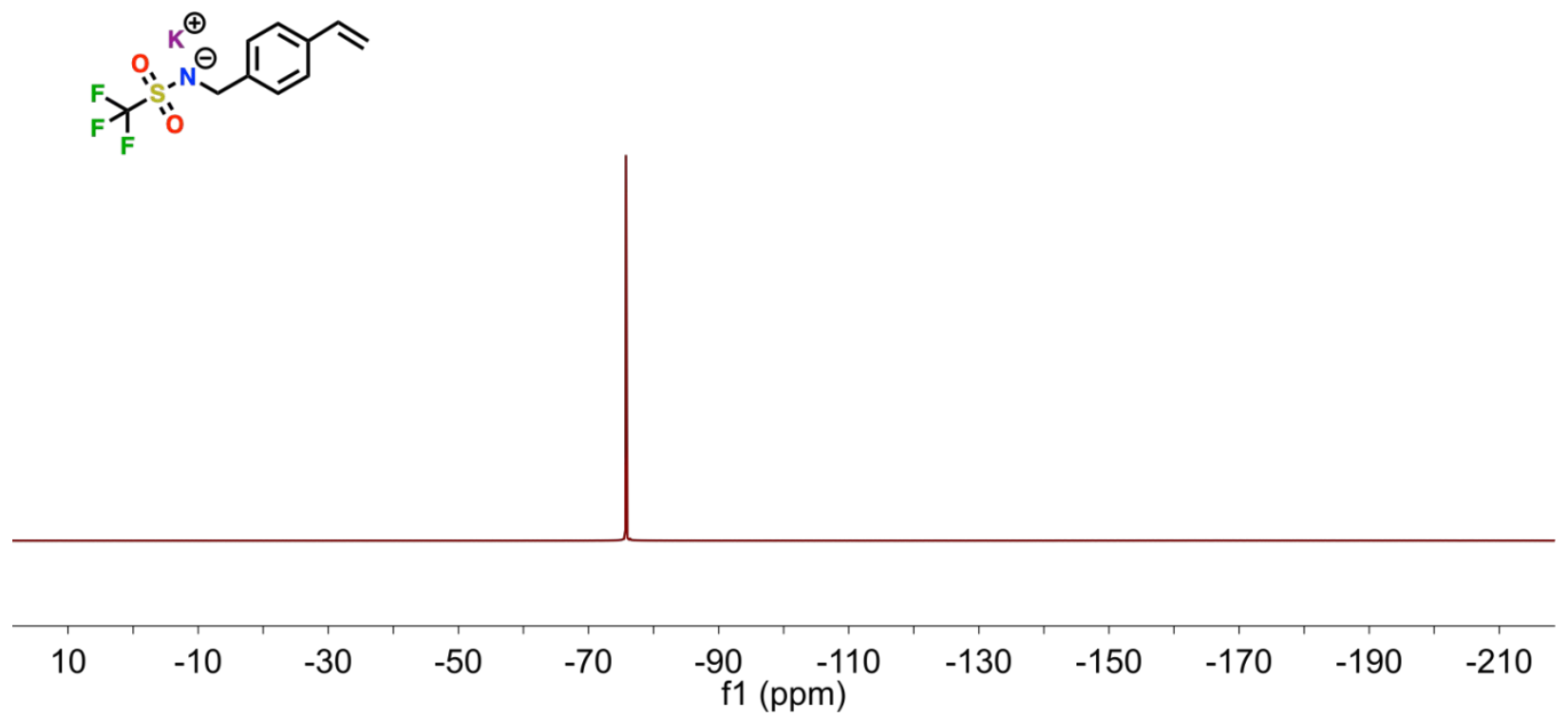

Figure S4. ${ }^{19} \mathrm{~F}$ NMR spectra of 4-methyl-styrene-type monomer in DMSO 

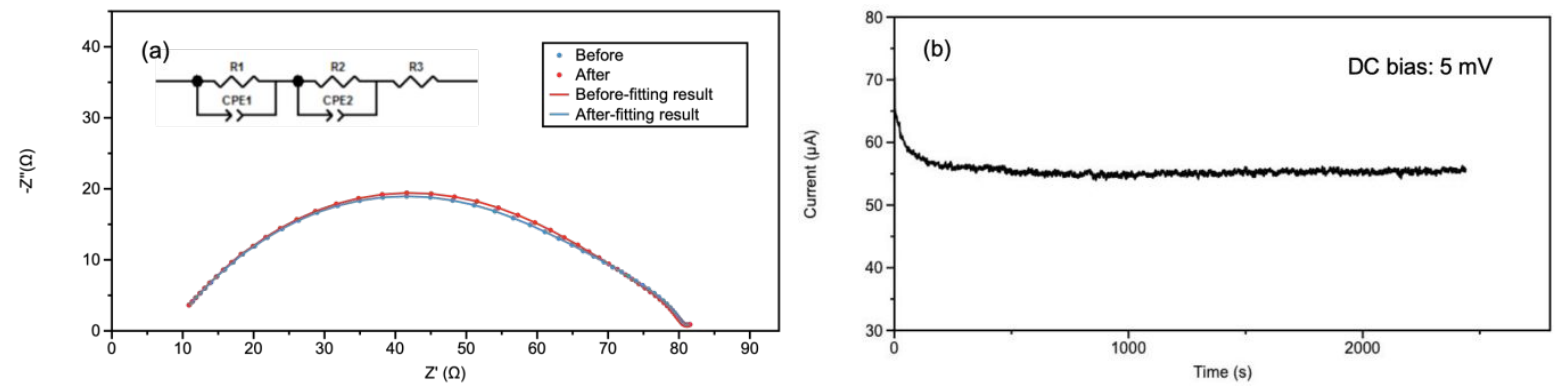

Figure S5. (a) Electrochemical impedance spectra before and after polarization. The inset is the fitting model. (b) Chronoamperometric curve of $\mathrm{K} / 0.5 \mathrm{M} \mathrm{KPF}_{6}$ in $\mathrm{DME} / \mathrm{K}$ symmetric cell for $\mathrm{K}$ ion transference number measurement, polarized with $5 \mathrm{mV}$ DC bias. 


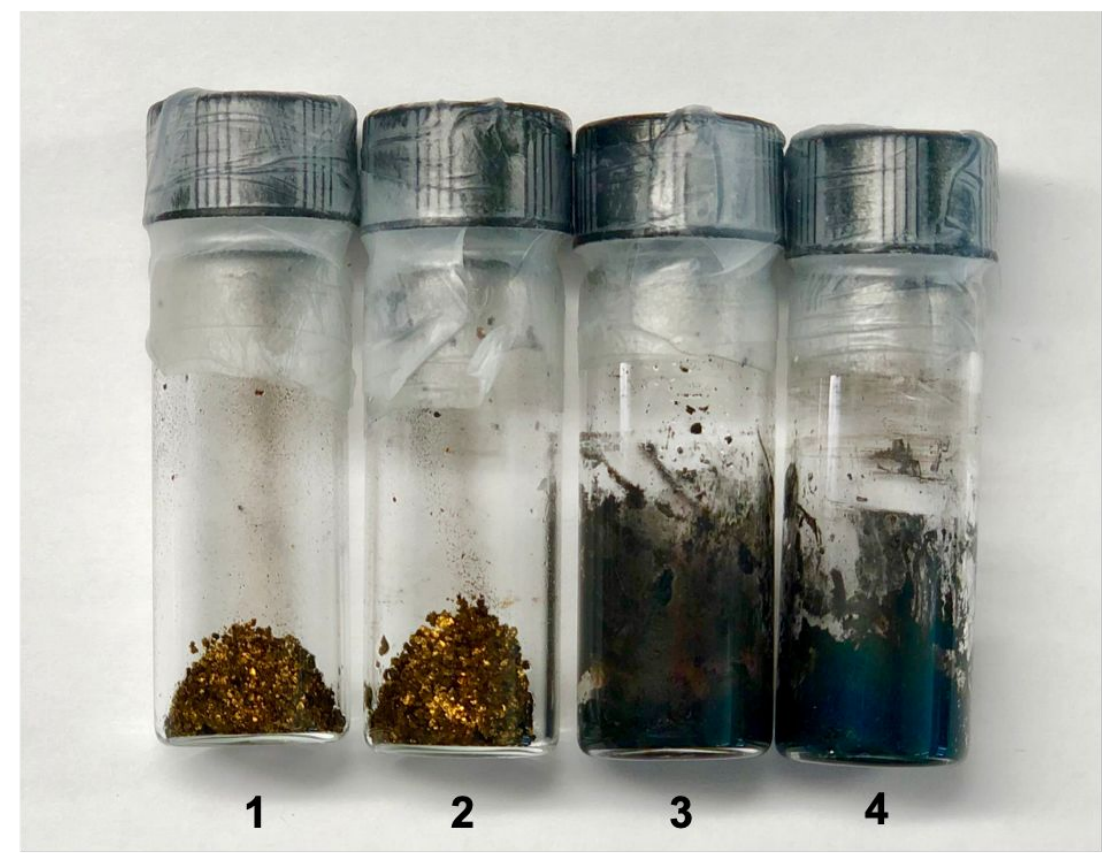

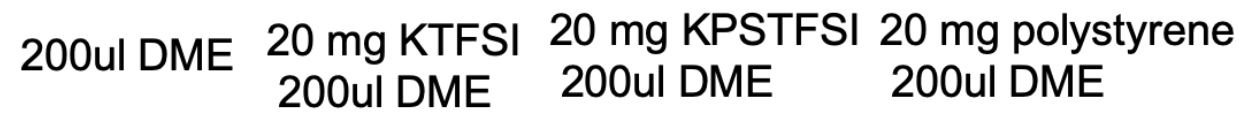

\section{$50 \mathrm{mg} \mathrm{KC8}$}

Figure S6. Digital photo of 1) $200 \mu \mathrm{L}$ DME; 2) $20 \mathrm{mg}$ KTFSI in $200 \mu \mathrm{L}$ DME; 3) $20 \mathrm{mg}$ KPSTFSI in $200 \mu \mathrm{L}$ DME; 4) $20 \mathrm{mg}$ polystyrene in $200 \mu \mathrm{L}$ DME reacted with $50 \mathrm{mg} \mathrm{KC} 8$ after 2 days. 


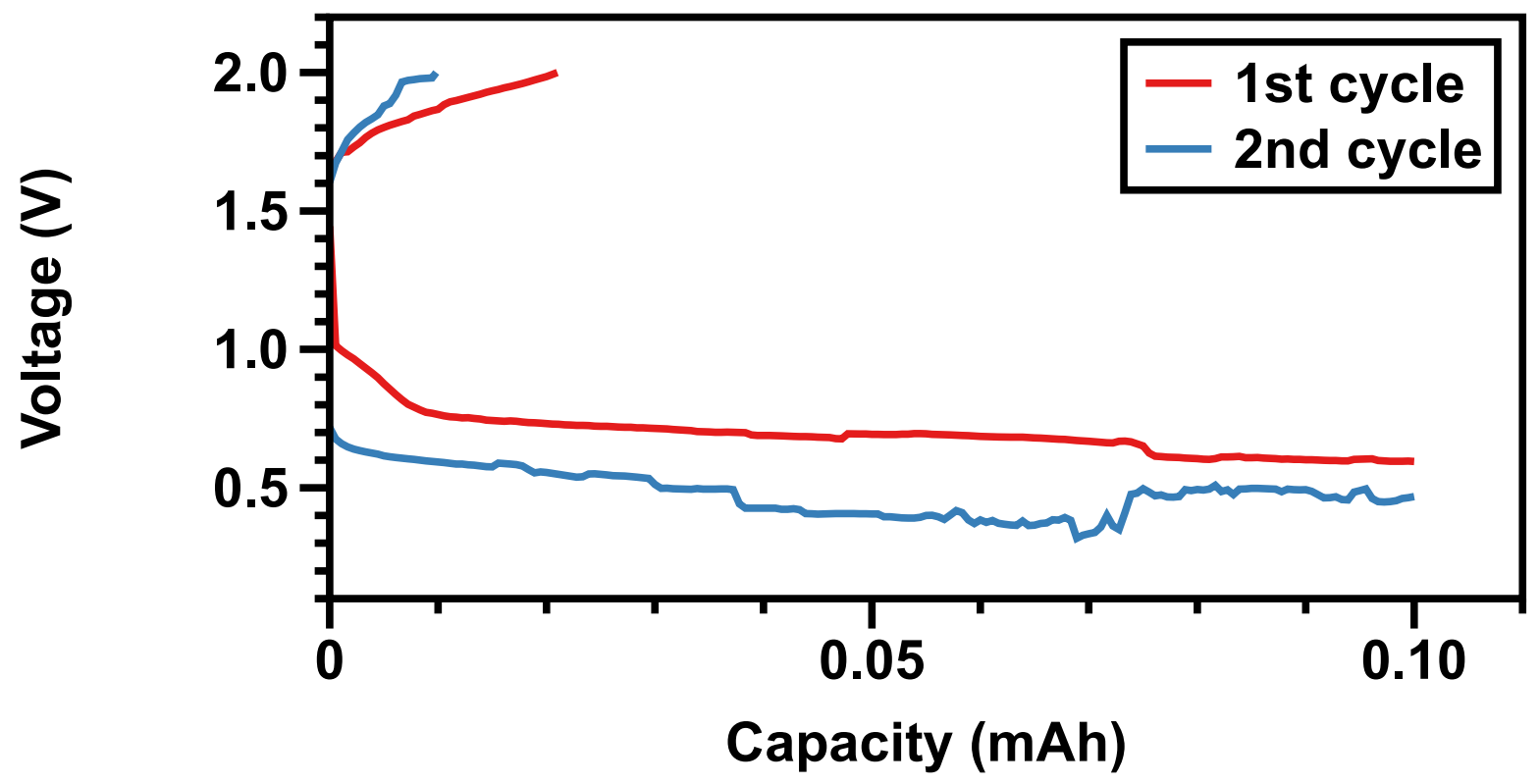

Figure S7. K/Graphite cell charge/discharge results using DME-swollen KPSTFSA with $\mathrm{Al}_{2} \mathrm{O}_{3}$. The current density is $0.1 \mathrm{~mA} / \mathrm{cm}^{2}$. The low Coulombic efficiency indicate the poor stability of KPSTFSA gel electrolyte with charged graphite. 


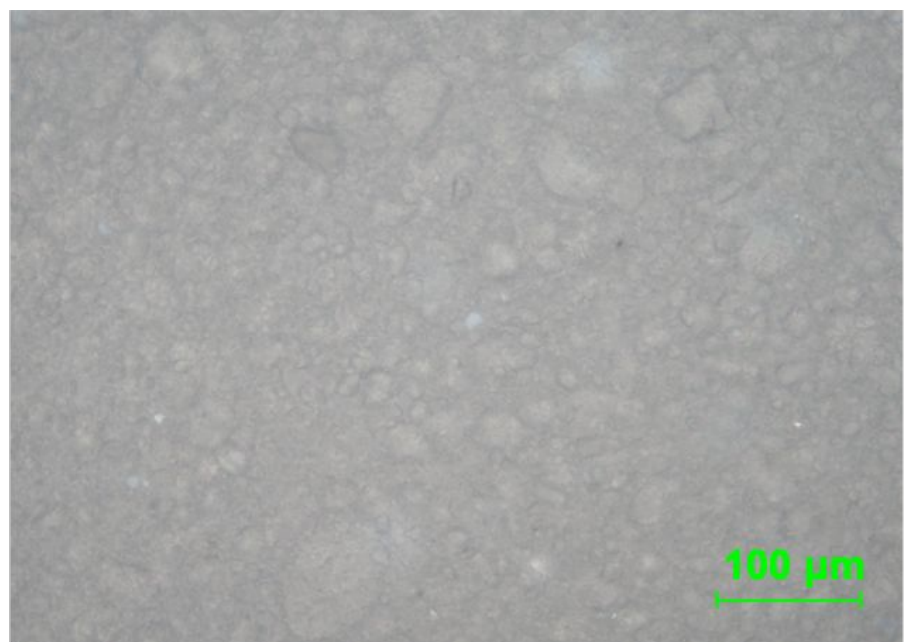

Figure S8. Optical microscope image of DME-swollen KPSTFSA gel electrolyte with $\mathrm{Al}_{2} \mathrm{O}_{3}$. 


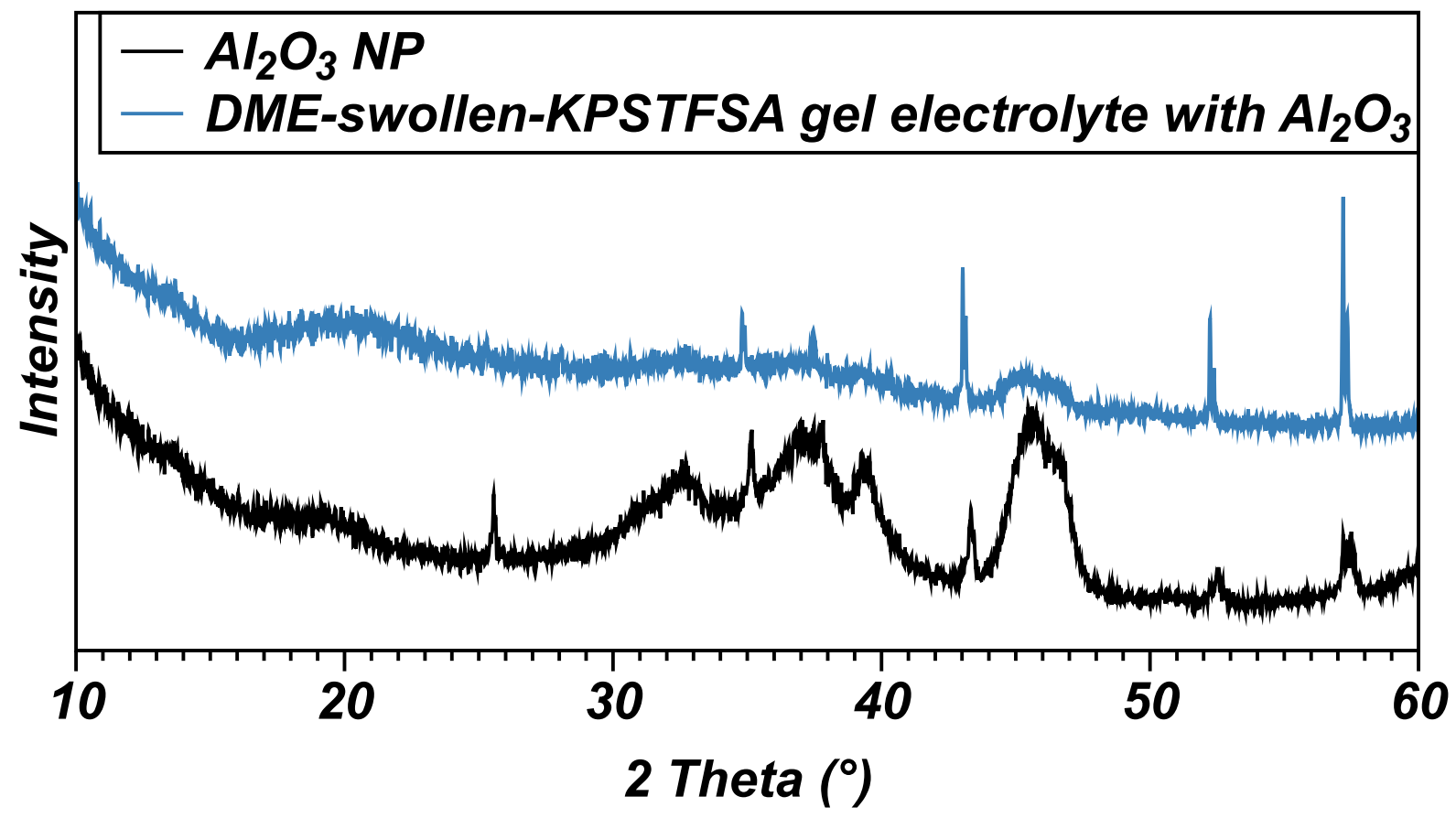

Figure S9. XRD patterns of $\mathrm{Al}_{2} \mathrm{O}_{3}$ nanoparticle and DME-swollen KPSTFSA gel electrolyte with $\mathrm{Al}_{2} \mathrm{O}_{3}$ nanoparticle. 
Table S1. The characterization data for GPC of KPSTFSI

\begin{tabular}{cccc}
\hline $\mathbf{M}_{\mathbf{n}}$ & $\mathbf{M}_{\mathrm{w}}$ & PDI & Appearance \\
\hline 411,500 & 696,600 & 1.69 & yellow powder \\
\hline
\end{tabular}


Table S2. The fitting results of the electrochemical impedance spectra before (Table on the Top) and after (Table on the Bottom) polarization for K/DME-swollen KPSTFSA with $\mathrm{Al}_{2} \mathrm{O}_{3}$ filler/K symmetric cell.

\begin{tabular}{cccc}
\hline Element & Value & Error & Error\% \\
\hline $\mathrm{R}_{\mathrm{b}}$ & 2010 & 4.1 & 0.21 \\
$\mathrm{CPE}_{\mathrm{b}}-\mathrm{T}$ & $5.970 \mathrm{E}-10$ & $4.978 \mathrm{E}-11$ & 8.3 \\
$\mathrm{CPE}_{\mathrm{b}}-\mathrm{P}$ & 0.8474 & 0.00545 & 0.64 \\
$\mathrm{Ri}$ & 18646 & 69.1 & 0.37 \\
$\mathrm{CPE}-\mathrm{T}$ & $9.622 \mathrm{E}-7$ & $1.161 \mathrm{E}-8$ & 1.2 \\
$\mathrm{CPE}_{\mathrm{i}}-\mathrm{P}$ & 0.7594 & 0.01726 & 0.22 \\
\hline & & & \\
\hline $\mathrm{Element}$ & Value & Error & Error\% \\
\hline $\mathrm{R}_{\mathrm{b}}$ & 2022 & 4.2 & 0.21 \\
$\mathrm{CPE}_{\mathrm{b}}-\mathrm{T}$ & $6.044 \mathrm{E}-10$ & $5.022 \mathrm{E}-11$ & 8.3 \\
$\mathrm{CPE}_{\mathrm{b}}-\mathrm{P}$ & 0.8466 & 0.00543 & 0.64 \\
$\mathrm{Ri}$ & 19547 & 73.4 & 0.38 \\
$\mathrm{CPE}_{\mathrm{i}}-\mathrm{T}$ & $9.740 \mathrm{E}-7$ & $1.158 \mathrm{E}-8$ & 1.2 \\
$\mathrm{CPE}_{\mathrm{i}}-\mathrm{P}$ & 0.7570 & 0.01705 & 0.23 \\
\hline
\end{tabular}

$t_{K-\text { ion }}=\frac{I^{s}\left(\Delta V-I^{0} R^{0}\right)}{I^{0}\left(\Delta V-I^{s} R^{s}\right)}=\frac{0.840 \mu A \times(20 \mathrm{mV}-0.895 \mu A \times 18646 \Omega)}{0.895 \mu A \times(20 \mathrm{mV}-0.840 \mu \mathrm{A} \times 19547 \Omega)}=0.87$ 